\title{
Production of Biodiesel from Parinari polyandra $B$. Seed Oil using Bio-Based Catalysts
}

\author{
O. $\operatorname{Amos}^{1}$, D. S. Ogunniyi ${ }^{2}$, T. E. Odetoye ${ }^{2 *}$ \\ ${ }^{1}$ Department of Chemistry, University of Ilorin, P.M.B 1515, Ilorin, Nigeria. \\ ${ }^{2}$ Department of Chemical Engineering, University of Ilorin, P.M.B 1515, Ilorin, Nigeria.
}

\begin{abstract}
Two agricultural residues, cocoa pod ash (CPA) and rice husk ash (RHA), were investigated as bio-based catalysts for the transesterification of Parinari polyandra seeds oil and the results obtained using these bio-based catalysts were compared with potassium hydroxide which is a conventional catalyst. Oil was extracted from parinari seeds and a yield of 57\% was obtained. Cocoa pod and rice husks were ashed in muffle furnace at $600{ }^{\circ} \mathrm{C}$ and then characterized. Atomic Absorption Spectrometric analysis indicated the metal constituents of CPA as $13.05 \mathrm{ppm}$ potassium, $6.65 \mathrm{ppm}$ sodium while RHA contained $3.24 \mathrm{ppm}$ potassium, $1.748 \mathrm{ppm}$ sodium, $0.053 \mathrm{ppm}$ iron, 1.575 ppm magnesium, $2.325 \mathrm{ppm}$ calcium and $0.009 \mathrm{ppm}$ aluminum. Various concentrations of KOH, CPA and RHA (0.5$0.4 \%$ ) were investigated in the transesterification reactions. Methanol - to - oil ratio of $6: 1$ with $1 \% \mathrm{KOH}, 2 \% \mathrm{RHA}$ and $4 \%$ CPA catalysts gave good biodiesel yields. The biodiesel yields of $99.94 \%, 98.61 \%$ and $88.85 \%$ were obtained with $1 \% \mathrm{KOH}, 4 \% \mathrm{CPA}$ and $2 \%$ RHA catalysts respectively. The properties of the biodiesel produced were determined and found to fall within the ASTM specification for standard biodiesels.
\end{abstract}

KEYWORDS: Biodiesel, parinari oil, cocoa pod ash, rice husk ash, transesterification.

[Received March 4 2016; Revised May 16 2016; Accepted May 22 2016]

\section{INTRODUCTION}

Cocoa pod husks and rice husks are agricultural wastes found in cocoa and rice processing industries (Ofori-Boateng and Lee, 2013). Recently, the increase in the production of cocoa has led to increase in the waste generated from cocoa production (Vriesmanna et al, 2011). The utilization of such agricultural residues as industrial raw materials is potentially sustainable, eco-efficient and economical since they are sourced as cheap, renewable raw material. It is noteworthy that cocoa pod ash is being used in some parts of West Africa to produce soap (Mensah and Agrrey, 2005) while rice husk ash has been evaluated as filler in rubber composite (Khalil et al, 2014).

Also, seed oils are regarded as renewable and potentially inexhaustible source of energy with their energy contents close to that of diesel fuel (Chindo et al, 2013). Consequently, alternative fuels from biomass resources, especially vegetable oils have been considered environmentally acceptable (Firrisa et al, 2014). The best method of reducing the high viscosity of vegetable oils is by transesterification. This is a simple reaction of converting vegetable oil to alkyl of fatty acids esters (biodiesel) by reacting it with alcohol. Specifically, oil triglyceride reacts with methanol to produce fatty acid methyl esters (FAME) and glycerol in the presence of a catalyst.

The oil or fat used for biodiesel production is determined by the abundance of seed oils that are available in a particular locality. Among the oils that have been used to produce biodiesel are rapeseed oil, thevetia oil (Chindo et al, 2014). Sunflower oil (Firrisa et al, 2014), soybean oil (Alnuami et al, 2014), jatropha (Silitonga et al, 2013). shea butter (Alamu and Enweremadu, 2010), karanj oil, (Choudhary and Yadav, 2013)

*Corresponding author's e-mail address: todetoye@yahoo.com and Moringa seed oil (Salaheldeen et al, 2015). However, there are a lot of tropical seed oils that are yet to be investigated for biodiesel production. Parinari polyandra Benth seed oil is one of them.

Parinari oil is an under-utilized oil with potential for industrial utilization particularly because of its relatively high oil yield and it has been classified as an inedible oil (Olatunji et al, 1996; Odetoye et al, 2014), Parinari plant can be found in the northern and middle belt areas of Nigeria (Keay, 1989). For the transesterification reaction to proceed to completion, a catalyst such as a strong acid or alkaline is often used to accelerate the reaction (Silitonga et al, 2013). Catalysts which have been investigated for the production of biodiesel include enzyme lipase (Parawira et al, 2010) and other conventional catalysts like $\mathrm{KOH}, \mathrm{NaOH}$, and $\mathrm{CH}_{3} \mathrm{ONa}$ (Silitonga et al, 2013).

The ashes of many agricultural residues are known to contain alkali metal carbonates (Mensah and Agrrey, 2005; Taiwo and Osinowo, 2001) which can serve as potential biobased catalyst for various reactions including transesterification. In this paper, we investigate the use of cocoa pod ash (CPA) and rice husk ash (RHA) agricultural residues as bio-based catalysts for the transesterification of parinari oil by methanol.

\section{MATERIALS AND METHODS}

\section{A. Collection and Dehulling of Seeds}

Parinari fruits were collected within Ilorin metropolis, Kwara state, Nigeria by plucking the ripe fruits in the month of April. The fruits were dehulled by breaking them into halves doi: http://dx.doi.org/10.4314/njtd.v13i1.5 
to obtain the oily kernels which were sun-dried for 7 days. Size reduction of the kernels was done by grinding with a laboratory mortar and pestle to increase the surface area for maximum oil extraction.

\section{B. Extraction and Refining of Seed Oil}

$100 \mathrm{~g}$ of the seed was weighed and extracted using Sohxlet extractor and $n$-hexane as the solvent. The extraction process lasted for 4 hours. The oil was recovered from the solvent by distillation process. The oil was then refined by successive steps of degumming, neutralization and bleaching according to the methods described in literature (Odetoye et al, 2014; Haas and Mittlebach, 2000).

\section{Characterization of Parinari Oil Sample}

The oil was analyzed for both physical and chemical properties using ASTM standard methods (1983) for the determination of density, specific gravity, viscosity, acid value, iodine value and saponification value. The fatty acid constituents of parinari oil were also determined on the Agilent Gas Chromatograph- Mass Spectrometer, model 6890N with Agilent Mass Selective Detector, 5973 series with NIST database.

\section{Preparation of the Catalysts}

Cocoa pod husks were collected from Ado-Ekiti, Ekiti State while rice husks were obtained from Ilorin, Kwara State, Nigeria. The cocoa pod husks were sun-dried for 5 days and then charred by burning in air. Ash was obtained from the char by placing the crucible-filled samples in the muffle furnace operated at $600^{\circ} \mathrm{C}$ for 35 minutes. This heating procedure was repeated until a constant weight was obtained in accordance with the method described in D482-80 (ASTM, 1983). Similarly, rice husk ash was obtained by following the same procedures described. The ashes of cocoa pod and rice husks were sieved to obtain an average particle size of $0.8 \mathrm{~mm}$. The ashes were also characterized using Atomic Absorption Spectrometer and they were used as catalysts in the transesterification processes.

\section{E. Preparation of Biodiesel}

The biodiesel samples were prepared using the refined parinari oil. Varied concentrations of the catalysts, ranging from $0.5-4 \%$ were used in the transesterification processes with methanol-to-oil ratio being 6:1. The reaction time $s$ were for a period of 2 hours. The fatty acid methyl esters were then separated from the glycerol using a separating funnel.

\section{F. Analyses of Biodiesels}

The biodiesel samples produced were analysed for their density, viscosity, specific gravity and acid values according to ASTM standards. Also, the samples were analysed by GC-
MS as described earlier and yields were quantified from the gas chromatograms.

\section{RESULTS AND DISCUSSION}

\section{A. Parinari oil Extraction and Properties}

The average oil yield of the parinari seeds was $57 \%$ on dry weight basis. The relatively high oil yield value indicates that parinari seeds are rich in oil. Figure 1 shows the chromatogram of the parinari oil while the percentage composition of the oil obtained is as presented in Table 1. Table 1 also shows the major fatty acids present in the parinari oil sample to consist mainly of n-hexadecanoic acid and 9, 12- Octadecadienoic acid. The properties of the parinari oil are shown in Table 2. The composition of the oil is slightly different from the composition earlier reported (Odetoye et al, 2014). The difference may be attributed to the time of harvest.

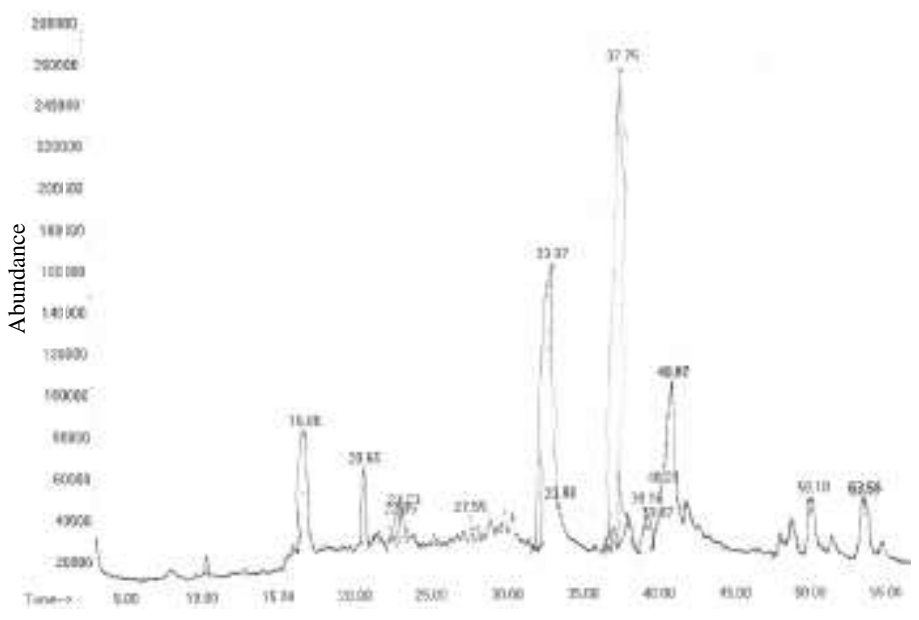

Figure 1: GC chromatogram of parinari oil.

Table 1: Percentage composition of parinari oil.

\begin{tabular}{lc}
\hline Component & Percentage (\%) \\
\hline n-hexadecanoic acid & 26.25 \\
9-Octadecenoic acid & 0.12 \\
Trans-2-hexadecenoic acid & 0.49 \\
9,12-Octadecadienoic acid & 18.10 \\
12,15-Octadecadienoic acid & 1.62 \\
2,5-Octadecadienoic acid & 0.32 \\
Phytol & 46.80 \\
Others & 6.30 \\
\hline
\end{tabular}

Oil obtained from parinari fruit harvested in April has been reported to vary in composition with the oil obtained from the fruit harvested in November (Motojesi et al, 2011).

The iodine value obtained for parinari oil in this work is lower than that reported in literature. The relatively lower iodine value may be attributed to the variation of fatty acid component in parinari oil with the time of harvest. Lower iodine values are however, preferred in oils which are to be used for biodiesel production (Silitonga et al, 2013). This result also indicates that the fruits harvested in April have a relatively lower iodine value, making their seed more suitable for biodiesel production (Motojesi et al, 2011). 
Table 2: Properties of parinari oil.

\begin{tabular}{|c|c|c|c|c|}
\hline \multirow[t]{2}{*}{ Property } & \multirow{2}{*}{$\begin{array}{c}\text { Crude } \\
\text { oil }\end{array}$} & \multirow{2}{*}{$\begin{array}{c}\text { Refined } \\
\text { oil }\end{array}$} & \multicolumn{2}{|c|}{ Literature values } \\
\hline & & & Source $\mathbf{A}^{*}$ & Source $B^{* * *}$ \\
\hline Density $\left(\mathrm{g} / \mathrm{cm}^{3}\right)$ & $\begin{array}{l}0.927 \\
\left(32^{\circ} \mathrm{C}\right)\end{array}$ & $\begin{array}{l}0.902 \\
\left(32^{\circ} \mathrm{C}\right)\end{array}$ & $\begin{array}{c}0.900-0.931 \\
\left(15^{\circ} \mathrm{C}\right)\end{array}$ & $\mathrm{Nr}$ \\
\hline Specific gravity & 0.939 & 0.899 & $\mathrm{Nr}$ & 0.9469 \\
\hline $\begin{array}{l}\text { Kinematic } \\
\text { Viscosity (cSt) } \\
\left(40^{\circ} \mathrm{C}\right)\end{array}$ & 25.74 & 20.20 & 38 & $\mathrm{Nr}$ \\
\hline Oil content $(\%)$ & 57 & 57 & 38 & 59.1 \\
\hline $\begin{array}{l}\text { Acid value (mg } \\
\mathrm{KOH} / \mathrm{g})\end{array}$ & 2.620 & 1.683 & 3.0 & 0.245 \\
\hline $\begin{array}{l}\text { Iodine value } \\
(\mathrm{g} / 100 \mathrm{~g})\end{array}$ & 80.71 & 80.71 & $120 \max$ & - \\
\hline $\begin{array}{l}\text { Saponification } \\
\text { value (mg } \\
\mathrm{KOH} / \mathrm{g})\end{array}$ & 118 & 112 & $\mathrm{Nr}$ & $\mathrm{Nr}$ \\
\hline $\begin{array}{l}\text { Ester value (mg } \\
\mathrm{KOH} / \mathrm{g} \text { ) }\end{array}$ & 115.38 & 110.32 & $\mathrm{Nr}$ & $\mathrm{Nr}$ \\
\hline
\end{tabular}

The acid value of $2.620 \mathrm{mg} \mathrm{KOH} / \mathrm{g}$ obtained for the crude oil is suitable for biodiesel production. After refining, the acid value reduced to $1.683 \mathrm{mg} \mathrm{KOH} / \mathrm{g}$, which accounts for $35 \%$ reduction in free fatty acids. This result indicates that refining the oil prior to biodiesel production is desirable. The viscosity value of $20.2\left(40^{\circ} \mathrm{C}\right)$ also justifies the need to trans-esterify the oil for reduced viscosity.

\section{B. Bio-based catalyst preparation and analysis}

The metal compositions of cocoa pod ash (CPA) and rice husk ash (RHA) are presented in Table 3. The metal composition results obtained for CPA was similar to the values reported in the literature (Taiwo and Osinowo, 2001). The metal contents $(\mathrm{K}, \mathrm{Na})$ were higher in CPA than in RHA.

Table 3: Metal compositions of CPA and RHA.

\begin{tabular}{|c|c|c|c|c|}
\hline Metal & $\begin{array}{l}\text { CPA } \\
\text { Concent } \\
\text { ration } \\
(\mathbf{p p m})\end{array}$ & $\begin{array}{l}\text { Literature } \\
\text { Value } \\
\text { (Taiwo and } \\
\text { Osinowo, } \\
\text { 2001) }\end{array}$ & $\begin{array}{l}\text { RHA } \\
\text { Concent } \\
\text { ration } \\
(\mathbf{p p m})\end{array}$ & $\begin{array}{l}\text { Literature } \\
\text { Value } \\
\text { ( Kalderis } \\
\text { et al, 2008) }\end{array}$ \\
\hline Potassium (K) & 13.05 & 20.50 & 3.240 & 2.51 \\
\hline Sodium (Na) & 6.65 & 8.00 & 1.748 & 1.75 \\
\hline Iron $(\mathrm{Fe})$ & $\mathrm{Nd}$ & $\mathrm{Nr}$ & 0.053 & 0.2 \\
\hline $\begin{array}{l}\text { Magnesium } \\
(\mathrm{Mg})\end{array}$ & $\mathrm{Nd}$ & $\mathrm{Nr}$ & 1.175 & $0.12-1.96$ \\
\hline Calcium (Ca) & $\mathrm{Nd}$ & $\mathrm{Nr}$ & 2.325 & 2.61 \\
\hline Aluminum (Al) & $\mathrm{Nd}$ & $\mathrm{Nr}$ & 0.009 & 0.36 \\
\hline
\end{tabular}

$\mathrm{Nd}=$ No determined

$\mathrm{Nr}=$ Not reported

\section{Parinari Oil Biodiesel and Properties}

The use of $1 \% \mathrm{KOH}, 2 \%$ RHA and 4\% CPA to transesterify parinari seed oil gave the best biodiesels yields (2\% concentration gave the neatest biodiesel among the RHA biodiesels). The corresponding gas chromatogram for each biodiesel is as shown in Figures 2-4. The properties of these biodiesels are also presented in Table 4. From GC/MS analysis of each biodiesel, $1 \% \mathrm{KOH}$ gave yield of $99.94 \%$, 4\% CPA gave $98.61 \%$ while $2 \%$ RHA gave $88.85 \%$ (Figures 2, 3 and 4).

Table 4: Properties of the biodiesels produced as compared with biodiesel standard and petro-diesel.

\begin{tabular}{|c|c|c|c|c|c|}
\hline Property & $\begin{array}{l}\text { A (1\% } \\
\text { KOH) }\end{array}$ & $\begin{array}{l}\text { B (2\% } \\
\text { RHA) }\end{array}$ & $\begin{array}{l}\text { C (4\% } \\
\text { CPA) }\end{array}$ & $\begin{array}{l}\text { Biodiesel } \\
\text { standard }^{\mathrm{a}}\end{array}$ & $\begin{array}{l}\text { Petro- } \\
\text { diesel } \\
\text { standard }\end{array}$ \\
\hline Density $\left(\mathrm{g} / \mathrm{cm}^{3}\right)$ & 0.895 & 0.697 & 0.807 & $\mathrm{Nr}$ & $\mathrm{Nr}$ \\
\hline $\begin{array}{l}\text { Kinematic } \\
\text { Viscosity } \\
\left(\text { at } 40^{\circ} \mathrm{C}\right) \\
\left(\mathrm{mm}^{2} / \mathrm{s}\right)\end{array}$ & 3.20 & 5.80 & 2.80 & $1.9-60$ & $\begin{array}{l}1.6-5.5 \\
\text { (at } \\
37.8^{\circ} \mathrm{C} \text { ) }\end{array}$ \\
\hline $\begin{array}{l}\text { Acid value (mg } \\
\mathrm{KOH} / \mathrm{g})\end{array}$ & 0.613 & 0.464 & 0.298 & $0.8 \max$ & 0.5 \\
\hline Flash point $\left({ }^{\circ} \mathrm{C}\right)$ & 175 & 150 & 165 & $100 \mathrm{~min}$ & $66 \mathrm{~min}$ \\
\hline $\begin{array}{l}\text { Ash content } \\
\text { (wt \%) }\end{array}$ & 0.002 & 0.010 & 0.03 & $0.05 \max$ & $0.01 \max$ \\
\hline Specific gravity & 0.862 & 0.609 & 0.705 & $\mathrm{Nr}$ & $\begin{array}{l}0.820- \\
0.860 \mathrm{~min}\end{array}$ \\
\hline
\end{tabular}

a ASTM standard for pure (100\%) biodiesel

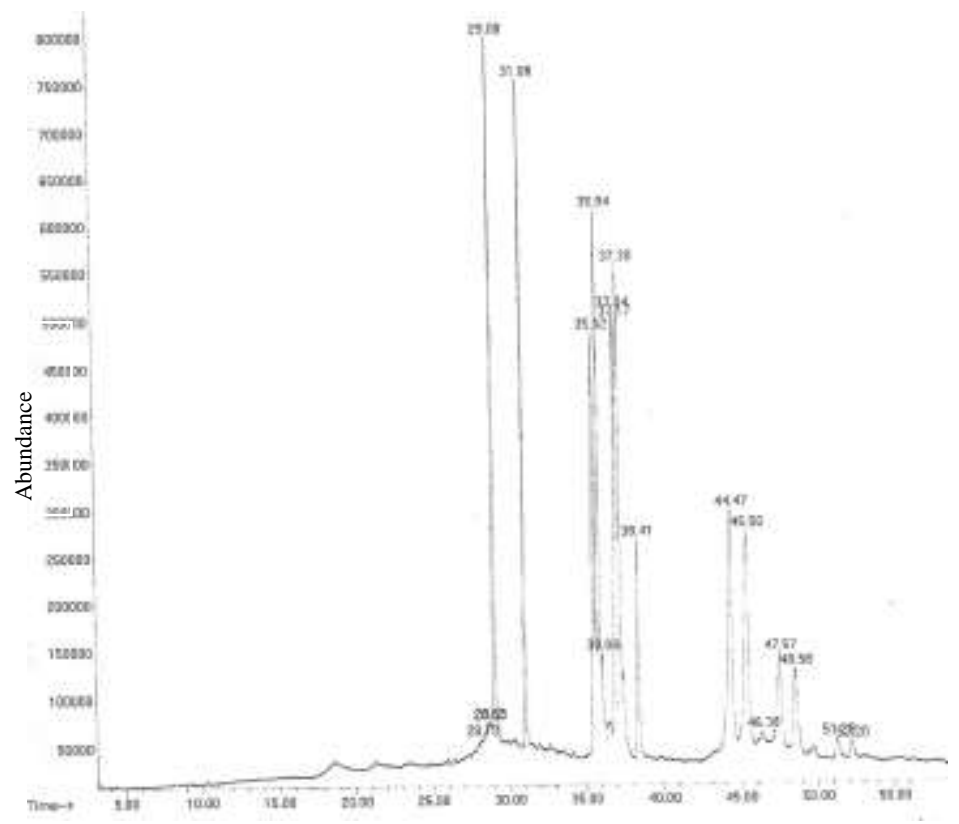

Figure 2: GC chromatogram of $1 \% \mathrm{KOH}$ biodiesel.

\section{CONCLUSION}

Parinari polyandra Benth seeds are rich in oil that can be explored for biodiesel production. The bio-based catalysts (cocoa pod ash and rice husk ash) have been used to effectively catalyze the transesterification of parinari oil. The physical and chemical properties of the oil compared favorably with those used in literature for biodiesel production. Although, the two bio-based catalysts were effective, CPA gave a neater and better yield of biodiesel than RHA. The biodiesels produced were considered suitable for use as alternative for petro-diesel since their properties compared favorably with ASTM specification for biodiesel standards. 


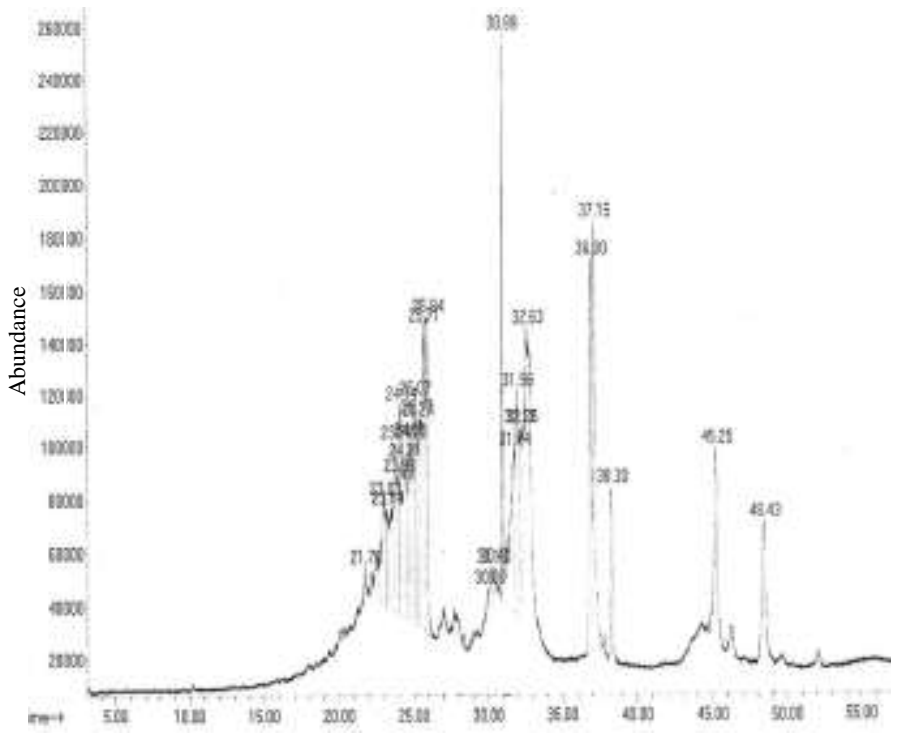

Figure 3: GC chromatogram of $2 \%$ RHA biodiesel.
ASTM (1983). Petroleum Products, Lubricants and Fossil Fuels, Annual Book of ASTM Standards, 05.01 277-279.

Bobinihi, F. F. (2005). Preparation and Evaluation of Oilmodified Alkyd Resin using Parinari polyandra Benth seed oil, M.Sc. Thesis submitted to Chemistry Department, University of Ilorin, Nigeria, unpublished 1-48.

Chindo, I., Y.; Danbature W. and Emmanuel M., (2013). Production of biodiesel from yellow oleander (Thevetia peruviana oil and its biodegradability, J. Korean Chem. Soc., 57 (3): 377-381.

Choudhary, U. and Yadav, S. K., (2013) Biodiesel Production from Karanj Crude Oil by Transesterification Process, International Journal on Emerging Technologies 4(2): 31-41.

Firrisa, M. T.; Duren I. V. and Voinov, (2014). A. Energy efficiency for rapeseed biodiesel production in different farming systems, Energy Efficiency, 7 (1): 79-95.

Garlapati V. K. and Kant R., Kumari A., Mahapatra P. Das P., and Banerjee R., (2013). Lipase mediated transesterification of Simarouba glauca oil: a new feedstock

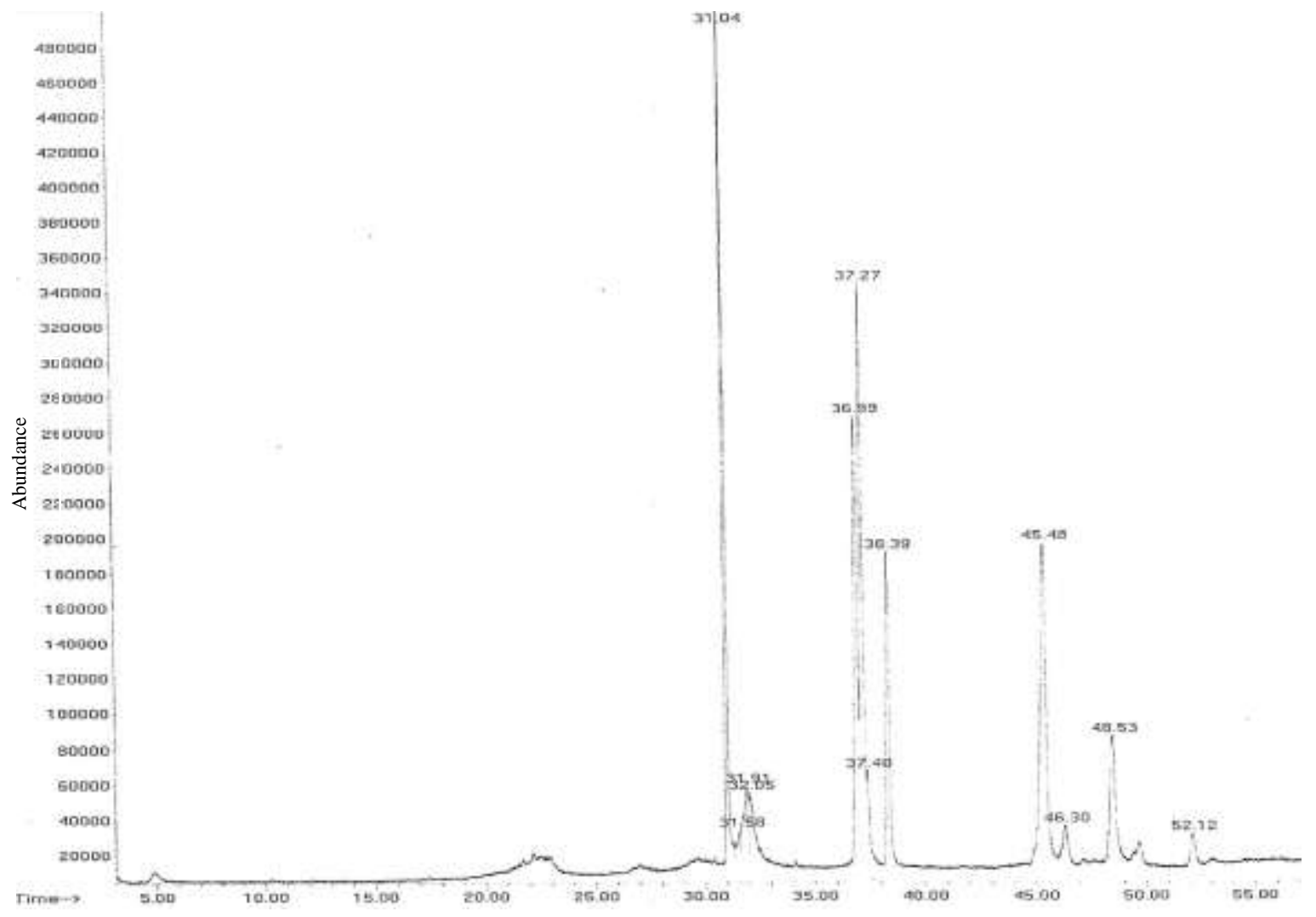

Figure 4: GC chromatogram of 4\% CPA biodiesel.

\section{REFERENCES}

Alamu, O.J. and Enweremadu C.C. (2010). Development and Characterization of Biodiesel from Shea Nut Butter, Int. Agrophys., 24: 29-34.

Alnuami, W.; Buthainah A.; Etti C. J.; Jassim L. I and Gomes G. A. (2011). Evaluation of Different Materials for Biodiesel Production, IJITEE, 3, (8): 60-65. for biodiesel production, Sustainable Chemical Processes, 1: (11) 2-6.

Haas, W. and Mittlebach M., (2000). Detoxification experiment with the seed oil from, Jatropha curcas. Ind. Crops Prod. 12, 111-118

Kalderis, D; Bethanis S.; Paraskeva P. and Diamadopoulos E., (2008). Production of activated carbon from bagasses and rice husk by a single stage chemical activation method at low retention times. Bioresour. Technol., 99, 6809- 6816. 
Keay, R.W.J. (1989).Trees of Nigeria, Claredon Press, Oxford, 184-186

Khalil, A.; Shaikh S.N., and Nudrat Z.R. (2014). Reinforcement of natural rubber hybrid composites based on marble sludge/Silica and marble sludge/rice husk derived silica, J. Adv. Res., Mar; 5(2): 165-173.

Mensah, B. and Agrrey, M., (2005).Recovery of Carbonates and hydroxides from cocoa pod ash: Analysis of Samples from Ochiso Liquid Soap Pilot Plant, Ghana J. Sci. 45, 35-39

Motojesi, O.; Ogunlaja A.S. and Amos O. Variation in lipid composition of the seed oil of Parinari polyandra Benth, Asian Journal of Applied Sciences, 4(2): 195 - 201(2011).

Odetoye, T.E.; Ogunniyi, D.S. and Olatunji, G.A. (2014). Refining and characterization of underutilized seed oil of Parinari polyandra Benth for industrial utilization, NJPAS, 27: 2538 - 2551.

Ofori-Boateng, C. and Lee K.T. (2013). The potential of using cocoa pod husks as green solid base catalysts for the transesterification of soybean oil into biodiesel: Effects of biodiesel on engine performance, Chemical Engineering Journal, 220: 395-401.
Olatunji, G.A, Ogunleye, A.J. and Lawani, S.A. (1996). Studies on the seed oil of Parinari polyandra Benth, Proximate Chemical Composition, Nigerian Journal of Science, 177-179.

Parawira, W. (2010). Biodiesel production from Jatropha curcas: A review, Sci. Res. Essays., 5(14): 1796-1808.

Salaheldeen, M., Aroua, M.K., Mariod A.A, Cheng S.F., Abdelrahman, M.A., Atabani, A.E. (2015). Physicochemical characterization and thermal behavior of biodiesel and biodiesel-diesel blends derived from crude Moringa peregrina seed oil, Energy Convers. Manage. 92: 535-542.

Silitonga, A.S.; Masjuki, H.H.; .Mahlia, T.M.I; Ong H.C.; Atabani, A. E. and Chong, W.T., (2013). A global comparative review of biodiesel production from Jatropha curcas using different homogeneous acid and alkaline catalysts: Study of physical and chemical properties, Renew. Sust. Energ. Rev., 24: 514-533.

Taiwo, O. E. and Osinowo F.A.O., (2001) Evaluation of various agro-wastes for traditional black soap production, Bioresour.Technol, 79: 95-97.

Vriesmanna, L.C.; Ambonib R.C. and Petkowicza C.L. (2011).Cocoa pod husks (Theobroma cacao L.): Composition and hot-water-soluble Pectins, Ind. Crop. Prod., 34: 11731181. 